\title{
Ultrasonic Carcass Assessment of Dorper and Dorper x Merino Lambs Using MLD and Body Measurements
}

\author{
Onur Yilmaz ${ }^{1}$, Sezen Ocak ${ }^{2 *}$, Sinan Ogun ${ }^{3}$ \\ ${ }^{1}$ Department of Animal of Science, Faculty of Agriculture, Adnan Menderes University, 09100 Aydın, Turkey \\ ${ }^{2}$ Department of Animal Science and Technologies, Faculty of Agricultural Sciences and Technologies, Nigde University 51240 Nigde, Turkey \\ ${ }^{3}$ Red Rock Agricultural Research and Development, 34360 Istanbul, Turkey \\ A R T I C L E I N F O \\ Article history: \\ Received 01 January 2016 \\ Accepted 10 February 2016 \\ Available online, ISSN: 2148-127X \\ Keywords: \\ Ultrasonic measurement \\ Dorper \\ Carcass \\ Lamb \\ Back fat thickness \\ ${ }^{*}$ Corresponding Author: \\ E-mail: sezenocak1@gmail.com

A B S T R A C T \\ Ultrasonic measurements of Musculus longissmus dorsi thoracis et lumborum (MLD) \\ were taken of Dorper $(n=99)$ and Dorper x Merino $(n=65)$ lambs at 156 days of age and \\ comparisons made to various body dimensions to ascertain whether sex, genotype, birth \\ type and live weight had any effect on these parameters. Lambs were weaned two months \\ after birth and placed ad libitum on basic dry land pasture during the draught spring and \\ summer months of 2014 in the arid southeastern region of Turkey. Least square means of \\ backfat thickness, skin+backfat thickness, muscle depth, body length, chest girth and live \\ weight, at the mean age of 156 days, were $0.17 \mathrm{~cm}, 0.32 \mathrm{~cm}, 1.75 \mathrm{~cm}, 63.30 \mathrm{~cm}, 72.37$ \\ $\mathrm{cm}$ and $25.16 \mathrm{~kg}$, respectively. Genotype was a statistically significant factor in terms of \\ back fat thickness (BFT), skin and backfat thickness (S+BFT), muscle depth (MD), body \\ length (BL) and live weight (LW). The study showed that Dorper and Dorper x Merino \\ genotypes into Turkey show a clear advantage over the native breeds in terms of meat \\ production and quality not to mention the high potential for lean carcass production. \\ Ultrasonic measurements of Longissimus thoracis et lumborum (MLD) will provide an \\ important contribution to selection index in breeding programs for Dorper and Dorper \\ crossbred genotypes. However estimation of genetic parameters are required in \\ containing a pedigree database in order to establish an effective selection index.
}

\section{Introduction}

Lamb meat is the preferred red meat option in most parts of Turkey, and is also the main source of income rather than wool or milk for the sheep industry in the country. In recent years the sheep population and their genetic quality for meat production has declined considerably and the nation has become an importer of lamb meat where once it exported such. The Dorper breed was first introduced to Turkey in 2012 by Zirve University Animal Research Centre with the aim of rectifying this shortfall. As an efficient feed converter Dorper was seen as the breed to answer Turkey's unproductive meat industry. The Dorper sheep is also regarded around the world as quality lamb meat producer. In lamb production growth rate and carcass characteristics of the animal are the main factors taken into account. In total age, genotype, gender, feeding regime, carcass weight and dressing percentages are the main elements that affect the quantity and quality of the meat produced. Meat production capacity has also been closely correlated with the body size of the animal. The main objective in the selection of farm animals, has depended on body length, height at withers and chest girth, as an indicator of high yielding meat producers in sheep herd breeding plan
(Akçapınar, 1983; Ünal, 2002; Yilmaz et al., 2013). Therefore keeping performance records and morphologically appraisals have often been important factors for sheep performance registration studies.

Although there are positive correlations between live weight and daily weight gain with feed conversion efficiency and carcass quality, these criteria are still somewhat insufficient for the animal breeding program aimed at improving carcass quality and quantity (Hanrahan, 1989; Tekin et al., 1993; Macit et al., 1996; Simm and Murphy, 1996; Stanford et al., 1998; Stanford et al., 2001; Simm et al., 2002; Yaralı et al., 2006; Cemal et al., 2007). In recent years, consumer demand has focused on lean meat, and as such new methods have been developed to determine the state of the carcass composition and quality on the live animal. The lamb meat industry has made it a priority to monitor production techniques to respond to consumer preferences. One of the main objectives in this industry sector has been to have an accurate and objective method for assessing the economically important traits of live animals, and determine the value of the carcass. Today's enhances ultrasound technology, which was first developed and 
used to estimate carcass characteristics by Temple et al., (1956), is increasingly being utilized to evaluate muscling in sheep in countries such as Australia, New Zealand and USA. In recent years, similar studies have also been carried out in Turkey (Cemal et al., 2007; Cemal et al., 2009; Y1lmaz et al., 2011; Yilmaz et al., 2014a; Yilmaz et al., 2014b). There are high phenotypic correlation coefficients between MLD and backfat thickness using ultrasound in live animals compared to the objective measurements examined from the carcass after slaughter (Fernandez et al., 1997; Fernandez et al., 1998). In this respect, ultrasound technology is becoming increasingly important to estimate these parameters (Sahin et al., 2008; Ekiz et al., 2009; Lambe et al., 2009a; Lambe et al., 2009b).

The aim of this study was to determine the backfat thickness and the Musculus longissmus dorsi thoracis et lumborum (MLD) properties using ultrasonic measurements and some body dimension measurements of Dorper and Dorper Merino crossbred lambs to evaluate the effects of sex, genotype, birth type and live weight on these parameters.

\section{Materials and Methods}

All experimental procedures were approved by the Zirve University Institutional Animal Care and Ethics Committee, Gaziantep, Turkey ensuring compliance with EC Directive 86/609/EEC for animal experiments

\section{Animals}

Animal material for the study consisted of 164 Dorper and Dorper x Merino crossbreed lambs (Figure 1) (Table 1) with an average of 156 days age raised under similar conditions at the Zirve University Middle East Sustainable Livestock Biotechnology and Agro-Ecology Research and Development Centre farm in South East region of Turkey. The area has winter heavy rainfall and dry summers with an annual precipitation rate of around $450 \mathrm{~mm}$. The geomorphological character of the area is marked with hilly surfaces consisting of limestone calcareous soils. The rangeland of the farm was dry land pasture improved with draught resistant species and animals ration consisted mainly of grazing with very limited grass hay supplementary feeding during the dry summer months. No supplementary feeding were provided.

\section{Body Measurements}

Body measurements and live weights of the lambs were determined at average age of 156 days. Live weights of the lambs were measured on digital scale with $0.05 \mathrm{~kg}$ sensitivity. Body length (BL) and chest girth (CG) measurements were made using a tape measure (Figure 2).

\section{Ultrasonic Measurements}

Measurements on the characteristics of Longissimus thoracis et lumborum (MLD) were performed by an experienced operator in vivo using ultrasound device (Esaote MyLab ${ }^{\mathrm{TM}}$ Five) with a $6 \mathrm{~cm} 7.5 \mathrm{MHz}$ linear probe on the muscle area between 12th and the 13th rib. The characteristics of MLD were determined to be backfat thickness (BFT), skin+backfat thickness (S+BFT) and muscle depth (MD) (Figure 3).

Table 1 Sample size of animal material

\begin{tabular}{l|rr|r}
\hline \multirow{2}{*}{ Genotype } & \multicolumn{2}{|c|}{ Gender } & \multirow{2}{*}{ Total } \\
\cline { 2 - 3 } & \multicolumn{1}{|c}{} & \multicolumn{1}{|c}{} & \\
\hline White Dorper (WD) & 20 & 15 & 35 \\
White Dorper X Merino (WD x M) & 12 & 20 & 32 \\
Black Dorper (BD) & 28 & 36 & 64 \\
Black Dorper X Merino (BD x M) & 16 & 17 & 33 \\
\hline Total & & & 164 \\
\hline
\end{tabular}
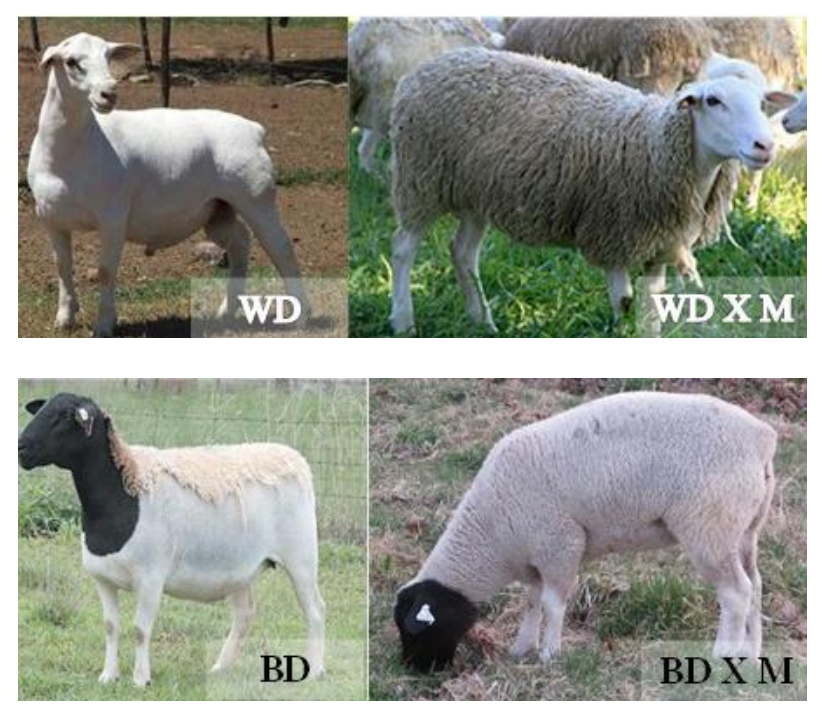

Figure 1 Breeds in the study (WD: White Dorper, WD $\mathrm{x}$ M: White Dorper x Merino crossbred, BD: Black Dorper, BD x M: Black Dorper x Merino crossbred)

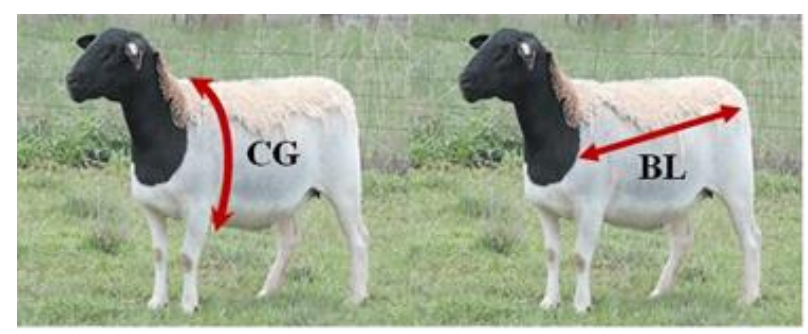

Figure 2 Body measurements used in this study (CG: Chest girth, BL: Body length)

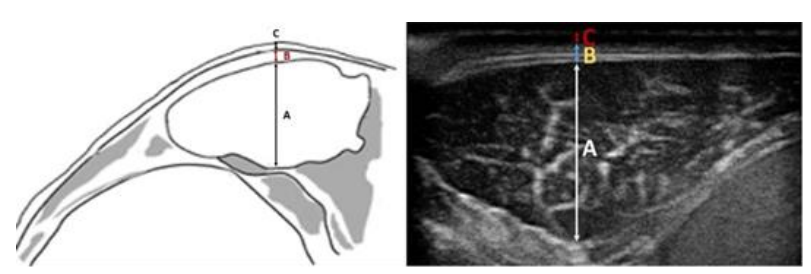

Figure 3. Measurement characteristics; A: Muscle depth, B: Backfat thickness, C: Skin 


\section{Statistical Analysis}

The UNIVARIATE procedure of SAS (1999) statistical package program was used to check normality of the data. The result of this analysis showed that the data for all the measured characteristics were normally distributed. Afterwards, GLM procedure in SAS (1999) was used to test the effects of sex, birth type and genotype in linear models on live-weight and ultrasonic measurements (BFT, S+BFT and MD) belong to MLD. The model used for the least-squares analysis was as follows:

Model for live weights of lambs during ultrasonic measurement;

$$
\mathrm{Y}_{\mathrm{ijkl}}=\mu+\mathrm{a}_{\mathrm{i}}+\mathrm{b}_{\mathrm{j}}+\mathrm{c}_{\mathrm{k}}+\mathrm{b}_{1}\left(\mathrm{X}_{\mathrm{ijk} \mathrm{l}}-\overline{\mathrm{X}}\right)+\mathrm{e}_{\mathrm{ijk} \mathrm{l}}
$$

Model for body measurements and ultrasonic measurements of MLD;

$$
\mathrm{Y}_{\mathrm{ijkl}}=\mu+\mathrm{a}_{\mathrm{i}}+\mathrm{b}_{\mathrm{j}}+\mathrm{c}_{\mathrm{k}}+\mathrm{b}_{2}\left(\mathrm{~A}_{\mathrm{ijk} \mathrm{l}}-\overline{\mathrm{A}}\right)+\mathrm{e}_{\mathrm{ijk} \mathrm{l}}
$$

Where,

$$
\begin{aligned}
& \mathrm{Y}_{\mathrm{ijkl}}=\text { Observations for live weight, body } \\
& \text { measurements and ultrasonic measurements } \\
& \mu \quad=\text { Overall mean of the trait } \\
& \mathrm{a}_{\mathrm{i}} \quad \text { =Fixed effect of sex (i=Male and female) } \\
& b_{j} \quad=\text { Fixed effect birth type }(j=1,2) \\
& \mathrm{c}_{\mathrm{k}}=\text { Fixed effect genotype }(\mathrm{k}=\mathrm{WD}, \mathrm{WD} \times \mathrm{M}, \mathrm{BD} \text {, } \\
& \text { BD x M) } \\
& \mathrm{b}_{1}=\text { Regression coefficient of lamb age } \\
& \mathrm{b}_{2} \quad=\text { Regression coefficient of live weight } \\
& \overline{\mathrm{X}}=\text { Mean lambs age } \\
& \mathrm{X}_{\mathrm{ijklm}}=\text { Age of lambs } \\
& \overline{\mathrm{A}} \quad=\text { Mean live weight of lambs } \\
& \mathrm{A}_{\mathrm{ijkl}}=\text { Live weight lambs } \\
& \mathrm{e}_{\mathrm{ijk}}=\text { Random errors with the assumption of } \mathrm{N}\left(0, \sigma^{2}\right)
\end{aligned}
$$

The phenotypic correlations between variables were obtained using the CORR procedure of the SAS (1999) statistical program.

\section{Results and Discussion}

The average age of the animal material was 156 days at the time of study. High variance was in both Dorper and Dorper x Merino crossbred lambs for live weight, age, backfat thickness (BFT) and skin + backfat thickness (S+BFT) (Table 2) when compared to other characteristics.

The least squares mean and standard error for ultrasound measurements of MLD live weight and body measurements are given in Table 3 .

Least square means of backfat thickness, skin+backfat thickness, muscle depth, body length, chest girth and live weight, were $0.17 \mathrm{~cm}, 0.32 \mathrm{~cm}, 1.75 \mathrm{~cm}, 63.30 \mathrm{~cm}, 72.37$ $\mathrm{cm}$ and $25.16 \mathrm{~kg}$, respectively. The analysis results indicated that there was a significant difference between sex in terms of MD, CG and LW $(\mathrm{P}<0.01)$ in the study. Males performed higher for CG and LW and females gave a higher reading for MD. Male and singleton lambs were found to be significantly heavier than the female and multiple birth lambs. Birth type showed no significance body measurement parameters.

Genotype was a statistically significant factor in terms of BFT, S+BFT, MD, BL and LW (P<0.01). MLD values obtained by ultrasonic measurement for White Dorper lambs were lower than for other genotypes in the study. The highest BFT and MD values were observed in BD $\mathrm{x}$ $\mathrm{M}$ crossbred lambs and $\mathrm{BD}$ lambs provided superior live weight readings than the other studied genotypes.

The coefficients for the regression of live weight on body and ultrasonic measurements were seen to be highly significant $(\mathrm{P}<0.001)$. Same could also be said of lamb age on live weight $(\mathrm{P}<0.001)$.

Phenotypic correlation coefficients between live weight, ultrasonic measurements and body measurements are given in Table 4.

All coefficient of correlation was found to be positive and significant $(* * * \mathrm{P}<0.01, * * \mathrm{P}<0.05)$. Variables such as $\mathrm{MD}$, body length, chest girth, which are directly related to live weight of animal, displayed very high positive correlations with one another (0.613-0.771). The largest correlations were between muscle depth of MLD and live weight $(r=0.613 ; \mathrm{P}<0.01)$ and $\mathrm{CG}$ and $\mathrm{LW}(\mathrm{r}=0.771$; $\mathrm{P}<0.01$ ), and lower but significant correlation was also calculated between ultrasonic measurements and body dimension traits $(r=0.199$ to $0.479 ; \mathrm{P}<0.01, \mathrm{P}<0.05)$. The correlation between muscle depth of MLD and live weight were higher than the other ultrasonic measurement parameters. A high correlation coefficient between live weight and body measurements were determined in this study.

Lamb age at time of measurement is important, as variation may exist when making comparative analysis between genetic evaluation programs which are based on ultrasonic measurements such as LAMBPLAN in Australia and the Suffolk sire reference plan in Canada and England (MLC 1987; Gilmour et al. 1994; Gallivan and Hosford 1997). High variation in BFT and S+BFT could be due to the very low fat readings with a mean of only 0.17 and 0.33 respectively. Results prove that decreased thickness result with a greater margin of error. This is in agreement with other studies (Cemal et al., 2007; Emenheiser et al., 2010; Y1lmaz et al., 2011; Yilmaz et al., 2014b). Statistical differences in MD, CG and LW was as expected for the gender.

It was an important in the study that the backfat thickness in the genotypes used was considerably lower than the numerous endemic Turkish sheep breeds such as Karya, Karacabey Merino, Kivircik and Awassi (Leeds et al., 2008; Ripoll et al., 2009; Orman et al., 2010; Y1lmaz et al., 2011; Santos et al., 2014; Yilmaz et al., 2014a; Yilmaz et al., 2014b). This suggested that the genotypes studied had significant potential for lean lamb production in Turkey. The thin layer of backfat in Dorper and Dorper $\mathrm{x}$ Merino lambs made these genotypes superior in terms of carcass quality. MLD values obtained in the present study were lower than those of earlier studies (Cemal et al., 2007; Theriault et al., 2009; Slosarz et al., 2011; Yilmaz et al., 2014b). The differences between the 
previous literature and the present study were mainly due to non-comparative aspects such as body weight, age and breed difference.

Our study's results for gender in terms of live weight was expected and in agreement with past studies (Mayaka et al., 1995; Fourie et al., 2002; Erol and Akçadag, 2009; Cam et al., 2010; Yilmaz et al., 2014a; Yilmaz et al., 2014b).

Although the live weight results in our study genotypes were lower when compared to Karayaka,
Akkaraman and Dorset Down x Akkaraman, the body length (BL) was in fact longer than those breeds for the similar age (Şireli and Ertuğrul, 2005; Cam et al., 2010). Many of research were reported higher chest girth value than the data obtained from the present study (Fourie et al., 2002; Şireli and Ertuğrul, 2005; Cam et al., 2010; Yilmaz et al., 2013). High body length and chest girth values showed that there are important findings in terms of growth characteristics in lamb.

Table 2 Basic statistics for ultrasound measurements of MLD, live weight and some body measurements

\begin{tabular}{l|ccccc}
\hline Variable & $\mathrm{N}$ & $\mathrm{X} \pm \mathrm{Sx}$ & Min & Max & $\mathrm{CV}(\%)$ \\
\hline LW $(\mathrm{kg})$ & 164 & $25.41 \pm 0.687$ & 11.50 & 53.50 & $34.61^{*}$ \\
BFT $(\mathrm{cm})$ & 164 & $0.17 \pm 0.004$ & 0.09 & 0.37 & $33.13^{*}$ \\
S+BFT $(\mathrm{cm})$ & 164 & $0.33 \pm 0.007$ & 0.14 & 0.58 & $26.65^{*}$ \\
MD $(\mathrm{cm})$ & 164 & $1.74 \pm 0.018$ & 0.91 & 2.38 & 12.88 \\
BL $(\mathrm{cm})$ & 164 & $63.26 \pm 0.499$ & 45.00 & 84.00 & 10.11 \\
CG $(\mathrm{cm})$ & 164 & $72.38 \pm 0.543$ & 60.00 & 95.00 & 9.61 \\
Age (Day) & 164 & $156.87 \pm 3.500$ & 60.00 & 264.00 & $28.61^{*}$ \\
\hline
\end{tabular}

LW: Live weight, BFT:backfat thickness, S+BFT: Skin with backfat thickness, MD: Muscle depth, BL: Body lenght, CG:Chest girth ${ }^{*}=$ indicates a significant variance $>20 \%$

Table 3 Least squares mean and standard error (SE) for ultrasound measurements of MLD, live weight and body measurements

\begin{tabular}{l|lllllll}
\hline Factors & $\mathrm{N}$ & $\mathrm{BFT}(\mathrm{cm})$ & $\mathrm{S}+\mathrm{BFT}(\mathrm{cm})$ & $\mathrm{MD}(\mathrm{cm})$ & $\mathrm{BL}(\mathrm{cm})$ & $\mathrm{CG}(\mathrm{cm})$ & $\mathrm{LW}(\mathrm{kg})$ \\
\hline Sex & & $\mathrm{P}=0.878$ & $\mathrm{P}=0.722$ & $\mathrm{P}=0.001$ & $\mathrm{P}=0.422$ & $\mathrm{P}=0.005$ & $\mathrm{P}=0.005$ \\
Male & 88 & $0.16 \pm 0.007$ & $0.32 \pm 0.010$ & $1.72 \pm 0.022$ & $63.51 \pm 0.559$ & $73.58 \pm 0.565$ & $24.72 \pm 0.482$ \\
Female & 76 & $0.16 \pm 0.007$ & $0.32 \pm 0.011$ & $1.81 \pm 0.024$ & $62.93 \pm 0.614$ & $71.55 \pm 0.621$ & $23.00 \pm 0.507$ \\
\hline Type of Birth & & $\mathrm{P}=0.271$ & $\mathrm{P}=0.438$ & $\mathrm{P}=0.095$ & $\mathrm{P}=0.788$ & $\mathrm{P}=0.524$ & $\mathrm{P}=0.000$ \\
1 & 136 & $0.17 \pm 0.005$ & $0.33 \pm 0.007$ & $1.74 \pm 0.015$ & $63.34 \pm 0.381$ & $72.28 \pm 0.385$ & $25.84 \pm 0.329$ \\
2 & 28 & $0.16 \pm 0.010$ & $0.31 \pm 0.015$ & $1.79 \pm 0.032$ & $63.10 \pm 0.835$ & $72.86 \pm 0.844$ & $21.88 \pm 0.706$ \\
\hline Genotype & & $\mathrm{P}=0.005$ & $\mathrm{P}=0.000$ & $\mathrm{P}=0.000$ & $\mathrm{P}=0.005$ & $\mathrm{P}=0.295$ & $\mathrm{P}=0.018$ \\
WD & 35 & $0.14 \pm 0.009$ & $0.27 \pm 0.014$ & $1.67 \pm 0.030$ & $63.21 \pm 0.786$ & $72.90 \pm 0.795$ & $23.81 \pm 0.672$ \\
WD X M & 32 & $0.16 \pm 0.010$ & $0.34 \pm 0.015$ & $1.81 \pm 0.032$ & $65.27 \pm 0.824$ & $73.54 \pm 0.833$ & $22.29 \pm 0.690$ \\
BD & 64 & $0.18 \pm 0.007$ & $0.35 \pm 0.011$ & $1.75 \pm 0.024$ & $62.98 \pm 0.617$ & $72.20 \pm 0.624$ & $24.76 \pm 0.539$ \\
BD X M & 33 & $0.18 \pm 0.010$ & $0.32 \pm 0.015$ & $1.84 \pm 0.033$ & $61.41 \pm 0.857$ & $71.63 \pm 0.866$ & $24.59 \pm 0.732$ \\
\hline Reg. Linear & & $\mathrm{P}=0.000$ & $\mathrm{P}=0.000$ & $\mathrm{P}=0.000$ & $\mathrm{P}=0.000$ & $\mathrm{P}=0.000$ & $\mathrm{P}=0.000$ \\
LW & & $0.002 \pm 0.001$ & $0.003 \pm 0.001$ & $0.018 \pm 0.002$ & $0.520 \pm 0.044$ & $0.585 \pm 0.044$ & $0.170 \pm 0.007$ \\
\hline Age (day) & & & & & & \\
General & 164 & $0.17 \pm 0.004$ & $0.32 \pm 0.006$ & $1.75 \pm 0.014$ & $63.30 \pm 0.351$ & $72.37 \pm 0.355$ & $25.16 \pm 0.325$ \\
\hline
\end{tabular}

WD: White Dorper, WD X M: White Dorper X Merino crossbred, BD: Black Dorper, BD X M: Black Dorper X Merino crossbred, LW: Live weight, BFT:Backfat thickness, S+BFT: Skin with backfat thickness, MD: Muscle depth, BL: Body length, CG:Chest girth

Table 4 Phenotypic correlation coefficients between live weight, ultrasonic measurements of MLD and body measurements

\begin{tabular}{|c|c|c|c|c|c|}
\hline Variables & LW & BFT & $\mathrm{S}+\mathrm{BFT}$ & MD & $\mathrm{BL}$ \\
\hline BFT & $0.352^{* *}$ & & & & \\
\hline $\mathrm{S}+\mathrm{BFT}$ & $0.386^{* *}$ & $0.773^{* * *}$ & & & \\
\hline MD & $0.613^{* * *}$ & $0.376^{* *}$ & $0.393^{* *}$ & & \\
\hline BL & $0.727^{* * *}$ & $0.183^{* *}$ & $0.199^{* *}$ & $0.450^{* *}$ & \\
\hline $\mathrm{CG}$ & $0.771^{* * *}$ & $0.234^{* *}$ & $0.317^{* *}$ & $0.479^{* *}$ & $0.741^{* * * *}$ \\
\hline
\end{tabular}

***:P<0.01, **:P<0.05, LW: Live weight, BFT:backfat thickness, S+BFT: Skin with backfat thickness, MD: Muscle depth, BL: Body lenght, $\mathrm{CG}$ :Chest girth 


\section{Conclusion}

Ultrasonic imaging system plays an important role in selection programs conducted for the improvement of meat quality characteristics in countries such as Australia, USA and New Zealand. Same could apply for Turkey in the future. Ultrasonic assessment results obtained in this study showed that recently introduced yet fast establishing Dorper and Dorper x Merino genotypes into Turkey show a clear advantage over the native breeds in terms of meat production and quality. We can clearly state that the introduced genotypes used in this study show significant potential for lean carcass production in Turkey. Ultrasonic measurements of MLD will provide an important contribution to selection index in breeding programs for Dorper and Dorper crossbred genotypes. However estimation of genetic parameters are required in containing a pedigree database in order to establish an effective selection index.

\section{References}

Akçapınar H. 1983. Alman Et Merinosu ve Karacabey Merinoslarının canlı ağırlık, beden yapısı ve yapağı verimi yönünden karşılaştırılması. Ankara Üniversitesi Veteriner Fakültesi Dergisi, 30: 201-215.

Cam MA, Oflaz M, Soydan E. 2010. Body measurements reflect body weights and carcass yields in Karayaka sheep. Asian Journal of Animal and Veterinary Advances, 5:120-127. DOI: 10.3923/ajava.2010.120.127.

Cemal İ, Karaca O, Altin T, Gökdal Ö, Yilmaz M, Yilmaz O. 2007. Ultrasound measurements of eye muscle properties and backfat thickness in Kivircik lambs. Journal of Biological Sciences 7:89-94. DOI: 10.3923/jbs.2007.89.94.

Cemal I, Karaca O, Yılmaz O, Yılmaz M. 2009. Karya kuzularda pazarlama dönemi canlı ağırlığı ile göz kası özelliklerine ait ultrason ölçüm parametreleri. 6. Ulusal Zootekni Bilim Kongresi. Erzurum-Turkey, 24-26 June 2009. pp. 63-69.

Ekiz B, Yılmaz A, Özcan M, Kaptan C, Hanoğlu H. 2009. Carcass measurements and meat quailty of Turkish Merino, Ramlic, Kivircik, Chois and Imroz lambs raised under an intensive production system. Meat Science, 82(1):64-70. DOI: 10.1016/j.meatsci.2008.12.001.

Emenheiser JC, Greiner SP, Lewis RM, Notter DR. 2010. Validation of live animal ultrasonic measurements of body composition in market lambs. Journal of Animal Science, 88(9):2932-2939. DOI: 10.2527/jas.2009-2661.

Erol H, Akçadag Hİ. 2009. Halk elinde yetiştirilen Karagül Koyun sürülerinde bazı verim özellikleri. Lalahan Hayvancılık Araştırma Enstitüsü Dergisi, 49:91-104.

Fernandez C, Gallego L, Quintanilla A. 1997. Lamb fat thickness and longissimus muscle area measured by a computerized ultrasonic system. Small Ruminant Research, 26: 277-282. DOI:10.1016/S0921-4488(97)00007-2.

Fernandez C, Garcia A, Vergara H, Gallego L. 1998. Using ultrasound to determine fat thickness and longissimus dorsi area on Manchego lambs of different live weights. Small Ruminant Research, 27:159-165. DOI:10.1016/S0921-4488(97)00034-5.

Fourie PJ, Neser FWC, Olivier JJ, Westhuizen VD. 2002. Relationship between production performance, visual appraisal and body measurements of young Dorper rams. South African Journal of Animal Science, 32:256-262.

Gallivan C, Hosford S. 1997. Environmental effect on weight, ultrasonic muscle depth and ultrasonic fat depth in Alberta Suffolk lambs. Annual Meeting Canadian Society of Animal Science. Montreal, Quebec, Canada, July 24-26. pp:739.
Gilmour AR, Luff AF, Fogarty NM, Banks R. 1994. Genetic parameters for ultrasound fat depth and eye muscle measurements in live Poll Dorset sheep. Australian Journal of Agricultural Research, 45: 1281-1291. DOI:10.1071/AR9941281.

Hanrahan JP. 1989. Altering reproductive rate in sheep:some genetic and non-genetic option. In: Reproduction, growth and nutrition in sheep (Drymundsson OR, Thorgeirsson S). Agricultural Research Institute and Agricultural Society of Iceland: Reykjavik, Iceland. pp. 45-55.

Lambe NR, Bünger L, Navajas EA, Roehe R Simm G. 2009a. Use of meat quality information in breeding programmes. In: Improving the sensory and nutritional quality of fresh meat (Kerry J, Ledward D). Woodhead Publishing: Cambridge, England. pp. 264-291.

Lambe NR, Navajas EA, Fisher AV, Simm G, Roehe R, Bünger L. 2009 b. Prediction of lamb meat eating quality in two divergent breeds using various live animal and carcass measurements. Meat Science, 83:366-37 DOI: 10.1016/j.meatsci.2009.06.007.

Leeds TD, Mouse MR, Notte DR, Zerb HN, Moffet CA, Lewis GS. 2008. B-mode, real-time ultrasound for estimating carcass measures in lives sheep: Accuracy of ultrasound measures and their relationships with carcass yield and value. Journal of Animal Science, 86:3203-3214. DOI: 10.2527/jas.2007-0836.

Macit M, Yaprak M, Aksoy A. 1996. Morkaraman Erkek Kuzuların Entansif Şartlardaki Besi Performansları İle Kesim ve Karkas Özellikleri. Yüzüncü Yıl Üniversitesi Ziraat Fakültesi Dergisi, 6:61-74.

Mayaka TB, Tchoumboue J, Manjeli Y, Tepuie A. 1995. Estimation of live body weight in West African Dwarf goats from heart girth measurements. Tropical Animal Health and Production, 28:126-128.

MLC. 1987. Sheep yearbook. Meat and Livestock Commission: Milton Keynes, United Kingdom.

Orman A, Caliskan GU, Dikmen S. 2010. The assessment of carcass traits of Awassi lambs by real-time ultrasound at different body weights and sexes. Journal of Animal Science, 88: 3428-3438. DOI: $10.2527 /$ jas.2009-2431

Ripoll G, Joy M, Alvarez-Rodriguez J, Sanz A, Teixeira A. 2009. Estimation of light lamb carcass composition by in vivo realtime ultrasonography at four anatomical locations. Journal of Animal Science 87:1455-1463. DOI: 10.2527/jas.2008-1285.

Sahin EH, Yardımcı M, Cetingul IS, Bayram I, Sengör E. 2008. The use of ultrasound to predict the carcass composition of live Akkaraman lambs. Meat Science, 79:716-721. DOI:10.1016/j.meatsci.2007.11.003.

Santos NPS, Neto CBO, Sarmento JLR, Bezerra LR, Oliveira RL, dos Santos GV, Neto AAR, Biagiotti D. 2014. Carcass traits and growth curve parameters in SantaInês Sheep. Journal of Agricultural Science, 6:180-187. DOI: 10.5539/jas.v6n5p180.

SAS.1999. The SAS System Version 8. SAS Institute Inc.: Cary, NC, US.

Simm G, Lewis RM, Grundy B, Dingwall WS. 2002. Responses to selection for lean growth in sheep. Animal Science, 74: 39-50.

Simm G, Murphy SV. 1996. The effect of selection for lean growth in Suffolk sires on the saleable meat yield of their crossbred progeny. Animal Science, 62:255-263. DOI: 10.1017/S1357729800014557.

Slosarz P, Stanisz M, Boniecki P, Przybylak A, Lisiak D, Ludwiczak A. 2011. Artificial neural network analysis of ultrasound image for the estimation of intramuscular fat content in lamb muscle. African Journal of Biotechnology, 10:1179211796. DOI: 10.5897/AJB11.197.

Stanford K, Bailey DRC, Jones SDM, Price MA, Kemp RA. 2001. Ultrasound measurements of longissimus dimensions and backfat in growing lambs: effects of age, weight and sex. Small Ruminant Research, 42:191-197. DOI:10.1016/S09214488(01)00252-8.

Stanford K, Jones SDM, Price MA. 1998. Methods of predicting lamb carcass composition: A Review. Small Ruminant Research, 29:241-254. DOI:10.1016/S0921-4488(97)00143-0. 
Şireli HD, Ertuğrul M. 2005. Akkaraman, GD1x GD1 (DorsetDown x Akkaraman) ve Akkaraman x GD1Genotipli Kuzularda Canlı Ağırlık ve Vücut Ölçülerinin Tekrarlanma Dereceleri. Tarım Bilimleri Dergisi, 11:1-6.

Tekin ME, Akmaz A, Kadak R, Nazlı M. 1993. Akkaraman, İvesi ve Merinos erkek kuzuların besi ve karkas özellikleri. Hayvancıllk Araștırma Dergisi 3: 98-102.

Temple RS, Stonaket HH, Howry D, Pasakony C, Hazeleu MH. 1956. Ultrasonic and conductivity methods for estimating fat thickness in live cattle. Proc West Sec Am Soc Anim Prod, 7: 477.

Theriault M, Pomar C, Castonguay FW. 2009. Accuracy of realtime ultrasound measurements of total tissue, fat, and muscle depths at different measuring sites in lamb. Journal of Animal Science, 87:1801-1813. DOI: 10.2527/jas.2008-1002.

Ünal N. 2002. Akkaraman ve Sakız x Akkaraman $F_{1}$ kuzularda yaşama gücü, büyüme ve bazı vücut ölçüleri. Turkish Journal of Veterinary and Animal Sciences, 26:109-116.

Yaralı E, Karaca O, Yılmaz O. 2006. Çiftlik hayvanlarında karkas kompozisyonu tahmininde görüntüleme sistemlerinin kullanımı. Hasad Hayvanc1lık Dergisi, 253: 58:64.
Yilmaz O, Cemal İ, Karaca O. 2013. Estimation of mature live weight using some body measurements in Karya sheep. Tropical Animal Health and Production 45: 397-403. DOI: 10.1007/s11250-012-0229-7.

Yilmaz O, Cemal İ, Karaca O, Ata N. 2014a. Association of Calpastatin (CAST) gene polymorphism with weaning weight and ultrasonic measurements of loin eye muscle in Kivircik lambs. Journal of the Faculty of VeterinaryMedicine, Kafkas University 20: 675-680. DOI: 10.9775/kvfd.2014.10816

Yilmaz O, Sezenler T, Alarslan E, Ata N, Karaca O, Cemal İ. 2014b. Karacabey Merinosu, Karya ve Kivircik kuzularda sütten kesim döneminde kabuk yağı kalınlığı ve Musculus longissmus dorsi thoracis et lumborum (MLD) derinliğinin ultrason ölçümleri. Kafkas Üniversitesi Veteriner Fakültesi Dergisi 20:829-834. DOI:10.9775/kvfd.2014.10859.

Yılmaz O, Cemal İ, Yılmaz M, Karaca O, Taşkın T. 2011. Eşme Kıvırcık melezi kuzularda pazarlama canlı ağırlı̆̆ı ve bel gözü kas1 ultrason ölçümleri. 7 Ulusal Zootekni Bilim Kongresi. Adana, Turkey, 14-16 Eylül 2011. pp. 157. 